\title{
PEMBELAJARAN MEMBACA MENGGUNAKAN METODE PHONIK DAN MEDIA GAMBAR ANAK TUNAGRAHITA DI SLB NEGERI PRINGSEWU
}

\author{
Ani Diana $^{1}$, Dwi Fitriyani ${ }^{2}$ \\ FKIP, Universitas Muhammadiyah Pringsewu (UMPRI) \\ Pos-el: anidiana@ stkipmpringsewu-lpg.ac.id ${ }^{1}$, dwifitri@ stkipmpringsewu-lpg.ac.id²
}

\begin{abstract}
Abstrak
Perkembangan ilmu pengetahuan dan teknologi menuntut terciptanya masyarakat yang gemar belajar. Proses belajar yang efektif antara lain dilakukan melalui membaca. Masyarakat yang gemar membaca memperoleh pengetahuan dan wawasan baru yang akan semakin meningkatklan kecerdasan sehingga mereka lebih mampu menjawab tantangan hidup pada masa-masa mendatang, maka membaca diberikan di semua tingkat pendidikan termasuk bagi anak-anak berkebutuhan khusus. Penelitian ini bertujuan untuk mengetahui dan mendeskripsikan peaksanaan metode pembelajaran membaca phonik dan media gambar bagi anak tunagrahita. Subjek penelitian ini anak tunagrahita di SLB Negeri Pringsewu. Teknik pengumnpulan data yang digunakan dalam penelitian ini adalah observasi, wawancara, dan tes hasil belajar. Data yang sudah didapatkan dianalisis dengan metode analisis kualitatif deskriptif. Dari hasil penelitian bahwa pembelajaran membaca menggunakan metode phonik dan media gambar pada 7 anak tunagrahita di SLB Negeri Pringsewu, kemampuan membaca anak-anaknya lebih baik.

Kata Kunci: pembelajaran membaca, metode phonik, media gambar, anak tunagrahita.
\end{abstract}

\begin{abstract}
The development of science and technology demands the creation of a society that likes to learn. An effective learning process, among others, is done through reading. People who like to read gain new knowledge and insights that will increase their intelligence so that they are better able to answer life's challenges in the future, so reading is given at all levels of education including for children with special needs. This study aims to identify and describe the implementation of learning methods for reading phonics and image media for mentally retarded children. The subject of this research was children with mental retardation in Pringsewu State SLB. The data collection techniques used in this study were observation, interviews, and learning outcomes tests. The data that has been obtained were analyzed using descriptive qualitative analysis method. From the results of the study that learning to read using phonic methods and image media on 7 mentally retarded children in Pringsewu State SLB, their children's reading ability was better.

Keywords: reading learning, phonic methods, image media, mentally retarded children.
\end{abstract}




\section{PENDAHULUAN}

Perkembangan ilmu pengetahuan dan teknologi menuntut terciptanya masyarakat yang gemar belajar. Proses belajar yang efektif antara lain dilakukan melalui membaca. Masyarakat yang gemar membaca akan memperoleh pengetahuan dan wawasan yang banyak dan aktual sehingga akan lebih siap untuk menjawab tantangan-tantangan hidup di masa yang akan datang. Walaupun informasi atau wawasan yang baru dapat ditemukan dari media lain seperti TV dan radio, namun peran membaca tak dapat digantikan sepenuhnya. Membaca tetap memegang peranan penting dalam kehidupan sehari-harikarena tidak semua informasi dapat diperoleh dari TV dan radio. Maka pembelajaran membaca diajarkan disemua jenjang pendidikan untuk melatih kemampuan membaca semua anak.

Kemampuan membaca harus dimiliki semua anak tak terkecuali bagi anak tunagrahita, dengan membaca anak dapat mengikuti kegiatan pembelajaran yang ada di sekolah. Dengan kata lain bahwa membaca merupakan dasar atau alat untuk menguasai berbagai ilmu pengetahuan yang ada. Bagi anak tunagrahita kesulitan belajar yang sering dialami adalah membaca, menulis dan berhitung. Anak dengan hendanya perkembangan kemampuan (tunagrahita), memiliki problema belajar yang disebabkan adanya hambatan perkembangan intelegensi, mental, emosi, sosial, dan fisik (Delphine, 2012: 2).

Bagi anak tunagrahita ini tidak mudah untuk belajar membaca dengan cepat karena kegiatan membaca sesuatu yang rumit. Sesuai dengan pendapat Farida Rahim mengatakan bahwa membaca adalah sesuatu yang rumit yang melibatkan banyak hal, tidak hanya sekedar melafalkan tulisan, tetapi juga melibatkan aktivitas visual, berpikir, psikolinguistik, dan metakognitif (2009: 2). Jadi guru harus dapat menguasai metode dan media pembelajaran yang tepat untuk mengajarkan kegiatan tersebut dengan baik agar tujuan pembelajaran yang akan dicapai tercapai.

Pada umumnya anak tungrahita tidak berkosentrasi dalam satu objek, fikiran terpecah sehingga kesulitan untuk menerima informasi dalam proses pembelajaran maupun dalam kehidupan sehari-hari.Untuk mendapatkan hasil belajar yang baik pada proses pembelajaran membaca dibutuhkan peranan guru yang maksimal. Misalkan dengan memberikan pelayanan khusus dan menggunakan metode serta media pembelajaran yang menarik dan menyenangkan. Sehingga pembelajaran 
yang dilaksanakan akan memotivasi siswa untuk mengikuti pembelajaran dengan baik daripada mengatakan bahwa kunci motivasi itu sederhana, tetapi tidak mudah untuk mencapainya (Rahim, 2009: 19).

Di SLB N Pringsewu terdapat tingkat SD, SMP dan SMA untuk anak tungrahita. Untuk tingkat SD terdapat siswa tunagrahita sedang menuju berat, dengan kemampuan membaca sangat kurang. Belum banyak mengenal huruf. Belum bisa membedakan antara huruf $\mathrm{B}$ dengan $\mathrm{P}$ dan D. Hanya mengenal huruf C, J, Y, L, Z, dan Q. Siswa tersebut kelas V bernama Mitun. Di tingkat SMP dan SMA tunagrahita sedang dan ringan. Rata-rata anak mengalami kesulitan untuk mengingat yang sudah diajarkan dan mengabungkan huruf menjadi suku kata dan kata.

Adapun cara mengatasi kekurangan membaca anak tunagrahita yaitu dengan cara memberikan pengayaan yang kreatif, pemberian bimbingan emosi dan penyesuaian sosial serta pembekalan keterampilan dengan menggunakan metode pembelajaran yang dapat mempertinggi proses belajar mengajar khususnya pada kemampuan membaca (Rahim, 2009: 105).

Metode dan media pembelajaran yang digunakan oleh peneliti yaitu metode phonik dan media gambar. Metode phonik atau metode membunyikan huruf, menitik beratkan kemampuan mensintesis rangkaian huruf menjadi kata yang berarti (Jamaris, 2009: 185). Dengan metode ini diharapkan anak tunagrahita akan lebih mudah untuk melakukan kegiatan membaca. Metode phonik yang peneliti lakukan dengan prosedur sintesis yang dilakukan dengan memperkenalkan huruf terlebih dahulu setelah itu disusun menjadi kata.

Metode pembelajaran yang digunakan didukung dengan media pembelajaran yaitu media gambar. Media gambar media yang paling umum dipakai. Dia merupakan bahasa yang umum yang dapat dimengerti dan dinikmati di manamana. Menurut Sadiman (2003:21) media gambar adalah sebuah gambar yang berkaitan dengan materi pelajaran yang berguna untuk menyampaikan pesan dari guru kepada siswa. Media gambar ini bisa membantu siswa untuk mengungkapkan informasi yang terkandung dalam masalah sehingga hubungan antar komponen dalam masalah tersebut bisa terlihat dengan lebih jelas.Diharapkan dengan media gambar maka anak akan lebih mudah memahami dan mengingatnya. Penelitian ini bertujuan untuk mengetahui dan mendeskripsikan peaksanaan metode 
pembelajaran membaca phonik dan media gambar bagi anak tunagrahita di SLB Negeri Pringsewu.

\section{METODE PENELITIAN}

Penelitian ini menggunakan metode penelitian kualitatif adalah penelitian yang digunakan untuk menyelidiki, menemukan, menggambarkan, dan menjelaskan kualitas atau keistimewaan dari pengaruh sosial yang tidak dapat dijelaskan, diukur atau digambarkan melalui pendekatan kuantitatif (Sugiyono, 2013: 15). Penelitian ini dilakukan di SLB Negeri Pringsewu. Objek penelitian kemampuan membaca siswa tunagrahita SLB Negeri Pringsewu menggunakan metode phonik dan media gambar dalam proses pembelajarannya.

Teknik pengumpulan data yang digunakan oleh peneliti dalam penelitian ini adalah triangulasi teknik yang berarti peneliti menggunkan teknik pengumpulan data yang berbeda-beda untuk mendapatkan data dari sumber yang sama. Peneliti menggunakan observasi, wawancara, dan tes. Observasi merupakan suatu proses yang kompleks, suatu proses yang tersusun dari pelbagai proses biologis dan psikhologis. Dua di antara yang terpenting adalah proses-proses pengamatan dan ingatan (Sutrisno Hadi dalam Sugiyono, 2013: 203).
Peneliti menggunakan observasi partisipan yaitu peneliti terlibat secara langsung di dalam obyek yang diamati. Peneliti mengamati proses pembelajaran membaca yang dilakukan guru kepada siswa tunagrahita dan hasil dari pembelajaran tersebut. Wawancara merupakan teknik pengumpulan data yang untuk mengetahui lebih mendalam obyek yang akan diteliti. Teknik wawancara yang dilakukan peneliti, peneliti mewawancarai guru dan siswa yang bersangkutan dan teknik tes untuk mengetahui kemampuan membaca anak tunagragihta di SLB N Pringsewu.

\section{HASIL DAN PEMBAHASAN}

Penelitian yang dilakukan peneliti terhadap tujuh anak tunagrahita SLB Negeri Pringsewu untuk mengetahui kemampuan membaca anak-anak tungrahita. Awal yang dilakukan dengan melakukan observasi dan wawancara. Dari hasil observasi dan wawancara terhadap guru dan anak yang bersangkutan terdapat dua anak yang mengalami kesulitan membaca. Sulit untuk menyatukan huruf menjadi kata.

Pembelajaran dilakukan dua kali pertemuan dan diakhiri dengan pemberian tes. Pertemuan pertama peneliti memberikan materi dengan memperkenalkan huruf terlebih dahulu, 
kemudian menyusun huruf menjadi suku kata dan menjadi kata sesuai dengan gambar yang ditanyangkan.

Dari hasil analisis yang peneliti lakukan terhadap tujuh anak tunagrahita di SLB Negeri Pringsewu menghasilkan bahwa anak-anak tersebut lebih tertarik dan lebih mudah mengingat huruf-huruf yang diajarkan. Anak-anak pun dapat menyatukan menjadi kata sesuai dengan gambar yang dilihat. Terlihat pada data di, sebagai berikut:

1. Mitun

Hasil dari observasi anak tersebut banyak tidak menghafal huruf dan tidak bisa memnyatukan huruf menjadi kata. Huruf yang belum dihafal B, D, E, F, G, H, J, M, N, T, V, dan P. Karena banyak huruf yang tidak dihafal anak tersebut maka kesulitan juga untuk menyatukan menjadi kata. Setelah dilakukan pembelajaran membaca menggunakan metode phonik dan media gambar Mitun dapat menambah hafalan hurufnya, sedangkan huruf yang belum dihafal yaitu menjadi $\mathrm{B}, \mathrm{E}, \mathrm{H}, \mathrm{J}, \mathrm{T}, \mathrm{V}$, dan $\mathrm{P}$. Mitun juga dapat menyatukan huruf menjadi kata sesuai dengan gambar yang ditanyangkan seperti kata mata, pipi, dagu, kaki dan gigi.

\section{Ana Faraditul Nisa}

Hasil dari observasi dan wawancara Ana tidak hafal huruf E, F, G, J, dan V. Pada saat menyatukan huruf anak tersebut sedikit kesulitan dan tidak mengingat kembali setelah usai pembelajaran. Setelah dilakukan pembelajaran membaca menggunakan metode phonik dan media gambar, Ana Faraditul Nisa dapat mengingat hurufhuruf yang tadinya tidak dihafal dapat dihafal dan dapat menyatukan hurufhuruf menjadi kata.

\section{Anggun}

Dari hasil observasi dan wawancara Anggun tidak menghafal huruf D, J, P, G dan V. Pada saat menyatukan huruf masih kesulitan. Setelah dilakukan pembelajaran membaca menggunakan metode phonik dan media gambar Anggun dapat menghafal huruf dan menyatukan menjadi kata, seperti mata, kaki, dagu, pipi, dan balon.

\section{Reza Sanditino}

Hasil dari observasi anak tersebut banyak tidak menghafal huruf dan tidak bisa memnyatukan huruf menjadi kata. Huruf yang belum dihafal B, D, E, F, G, H, J, M, N, T, V, L, dan P. Karena banyak huruf yang tidak 
dihafal anak tersebut maka kesulitan juga untuk menyatukan menjadi kata. Setelah dilakukan pembelajaran membaca menggunakan metode phonik dan media gambar Reza dapat menambah hafalan hurufnya, sedangkan huruf yang belum dihafal yaitu menjadi $\mathrm{B}, \mathrm{H}, \mathrm{J}, \mathrm{T}, \mathrm{V}$, dan $\mathrm{P}$. Reza juga dapat menyatukan huruf menjadi kata sesuai dengan gambar yang ditanyangkan seperti kata mata, pipi, dagu, kaki, bebek dan gigi.

\section{Dwi Hariyanto}

Hasil dari observasi dan wawancara Ana tidak hafal huruf E, F, J, dan V. Pada saat menyatukan huruf anak tersebut sedikit kesulitan dan tidak mengingat kembali setelah usai pembelajaran. Setelah dilakukan pembelajaran membaca menggunakan metode phonik dan media gambar, Dwi Hariyanto dapat mengingat hurufhuruf yang tadinya tidak dihafal dapat dihafal dan dapat menyatukan hurufhuruf menjadi kata.

\section{Sherlyna Herawati}

Hasil dari observasi dan wawancara Ana tidak hafal huruf E, F, G, J, T dan V. Pada saat menyatukan huruf anak tersebut sedikit kesulitan dan tidak mengingat kembali setelah usai pembelajaran. Setelah dilakukan pembelajaran membaca menggunakan metode phonik dan media gambar, Sherlyna Herawati dapat mengingat huruf-huruf yang tadinya tidak dihafal dapat dihafal dan dapat menyatukan huruf-huruf menjadi kata.

\section{Minarsih}

Hasil dari observasi dan wawancara Ana tidak hafal huruf $\mathrm{J}$ dan V. Pada saat menyatukan huruf anak tersebut sedikit kesulitan dan tidak mengingat kembali setelah usai pembelajaran. Setelah dilakukan pembelajaran membaca menggunakan metode phonik dan media gambar, Minarsih dapat mengingat huruf-huruf yang tadinya tidak dihafal dapat dihafal dan dapat menyatukan huruf-huruf menjadi kata.

Dari hasil penelitian ini bahwa pembelajaran membaca menggunakan metode phonik dan media gambar pada anak tunagrahita di SLB Negeri Pringsewu, kemampuan membaca anakanaknya lebih baik. Dua anak yang tadinya kesulitan dalam menghafal huruf dan menyatukan menjadi kata setelah dilakukan pembelajaran menggunakan metode dan media tersebut dapat mengurangi yang tadinya tidak dihafal 
Ani Diana...

menjadi hafal dan sudah menambhak dapat membaca atau menyatukan menjadi kata.

\section{SIMPULAN}

Dari hasil penelitian ini bahwa pembelajaran membaca menggunakan metode phonik dan media gambar pada 7 anak tunagrahita di SLB Negeri Pringsewu, kemampuan membaca anakanaknya lebih baik. Dua anak yang tadinya kesulitan dalam menghafal huruf dan menyatukan menjadi kata setelah dilakukan pembelajaran menggunakan metode dan media tersebut dapat mengurangi yang tadinya tidak dihafal menjadi hafal dan sudah menambhak dapat membaca atau menyatukan menjadi kata.

\section{DAFTAR PUSTAKA}

Arief S. Sadiman. 2003. Media Pendidikan. Jakarta: Raja Grafindo Persada.

Bandi Delphine. (2013). Pembelajaran Anak Tunagrahita. Bandung: PT. Refika Aditama.

Farida Rahim. (2009). Pengajaran Membaca di Sekolah Dasar. Jakarta: PT. Bumi Aksara.

Martini Jamaris. (2009). Kesulitan Belajar Perpektif, Asesmen dan Penanggulangannya. Jakarta: Yayasan Penamas Murni.
Sugiyono. (2013). Metode Penelitian Pendidikan (Pendekatan Kuantititatif, kualitatif, dan R\&D). Bandung: Alfabeta. 